\title{
Potential Source Identification for Aerosol Concentrations over a site in Northwestern India
}

Swagata Payra Centre of Excellence in Climatology, Birla Institute of Technology, Mesra, Jaipur Campus, 27 MIA Jaipur 302017 Rajasthan, India. E-mail: spayra@gmail.com

Pramod Kumar Centre for Atmospheric and Oceanic Science, Indian Institute of Science (IISc), Banglore, 560012, India, E-mail: pramodchauhan@gmail.com

Sunita Verma Centre of Excellence in Climatology, Birla Institute of Technology, Mesra, Jaipur Campus, 27 MIA Jaipur 302017 Rajasthan, India. E-mail: verma.sunita@gmail.com

Divya Prakash Centre of Excellence in Climatology, Birla Institute of Technology, Mesra, Jaipur Campus, 27 MIA Jaipur 302017 Rajasthan, India. E-mail: divyaprakashyadav@gmail.com

Manish Soni Centre of Excellence in Climatology, Birla Institute of Technology, Mesra, Jaipur Campus, 27 MIA Jaipur 302017 Rajasthan, India. E-mail: manas.soni@gmail.com

Corresponding Author: Sunita Verma Centre of Excellence in Climatology, Birla Institute of Technology, Mesra, Jaipur Campus, 27 MIA Jaipur 302017 Rajasthan, India. E-mail: verma.sunita@ bitmesra.ac.inTelephone: +91 9610865724/6 


\section{ABSTRACT}

The collocated measurements of Aerosols Size Distribution (ASD) and Aerosol Optical Thickness (AOT) are analyzed simultaneously using Grimm aerosol spectrometer and MICROTOP II Sunphotometer respectively over Jaipur, capital of Rajasthan in India. The contrast temperature characteristics during winter and summer seasons of year 2011 are investigated in the present study. The total aerosol number concentration (TANC, 0.3-20 um) during winter season was observed higher than in summer time and it was dominated by fine aerosol number concentration (FANC $<2 \mu \mathrm{m}$ ). Particles smaller than 0.8 micrometer (at aerodynamic size) constitute $~ 99 \%$ of all particles in winter and $\sim 90 \%$ of particles in summer season. However, particles greater than $2 \mu \mathrm{m}$ contribute $\sim 3 \%$ and $\sim 0.2 \%$ in summer and winter seasons respectively. The aerosols optical thickness shows nearly similar AOT values during summer and winter but corresponding low Angstrom Exponent (AE) values during summer than winter, respectively. In this work, Potential Source Contribution Function (PSCF) analysis is applied to identify locations of sources that influenced concentrations of aerosols over study area in two different seasons. PSCF analysis shows that the dust particles from Thar Desert contribute significantly to the coarse aerosol number concentration (CANC). Higher values of the PSCF in north from Jaipur showed the industrial areas in northern India to be the likely sources of fine particles. The variation in size distribution of aerosols during two seasons is clearly reflected in the log normal size distribution curves. The log normal size distribution curves reveals that the particle size less than $0.8 \mu \mathrm{m}$ is key contributor in winter for higher ANC.

Keywords: Aerosol number concentration, Size distribution, AOT, PSCF 


\section{Introduction}

Aerosols are a major component of our environment and play an important role in the climate of the Earth-atmosphere system by means of their direct and indirect impact on climate (Schwartz et al., 1995). Atmospheric aerosol particles are one of the most variable components of the Earth's atmosphere and influence the energy budget and climate (Remer et al., 2005).

Aerosol number concentration and size distribution plays a crucial role in shaping Earth's radiation budget by scattering and absorption of sunlight in atmosphere. Scattering and absorption coefficient is an important parameter which strongly depends on particle's physical and chemical property. One of the key physical parameters of aerosols is the number size distribution, and especially for the climate effects, the size distribution in the sub-micron range. Most of the monitoring networks across the world measures PM $_{10}$ and $\mathrm{PM}_{2.5}$ (mass of particulate matter smaller than 10 and $2.5 \mu \mathrm{m}$ in aerodynamic diameter, respectively). Measurement of aerosol particle number size distribution was carried out in many cities of the world i.e. Birmingham (Harrison et al., 1999), Atlanta (Woo et al., 2001), Helsinki (Buzorius et al., 1999, Hussein et al., 2004), Leipzig (Wehner and Wiedensohler, 2003), Pittsburgh (Stanier et al., 2004), Beijing (Wu et al., 2008). These studies showed the seasonal variation with low aerosol number concentration in summer while high during winter.

In India the majority of observations are from coastal or urban locations. A high particulate matter concentration (Bhanarkar et al. 2002; Mitra and Sharma 2002; Gajananda et al. 2005; Chatterjee et al. 2010) has been reported from Indian cities. Kumar and Sarin (2009) reported mass concentrations of fine particulate matter less than or equal to $2.5 \mu \mathrm{m}\left(\mathrm{PM}_{2.5}\right)$ and coarse $\left(\mathrm{PM}_{10-2.5}\right)$ mode aerosols to vary from 1.6 to 46.1 and 2.3 to $102 \mu \mathrm{g} / \mathrm{m}^{3}$, respectively over the annual seasonal cycle during 2007 at a highaltitude site (Mt. Abu) in a semi-arid region. The aerosol number concentration during fireworks and vehicular emission is carried out by researcher in India (Singh et al., 2003; Kulshrestha et al., 2004; Pant et al., 2006; Pant et al., 2010; Majumdar and Nema, 2011; Sharma et al., 2011; Prakash et al., 2013; Saha et al., 2014; etc.). 
However, at large, the semi-arid region over India there is a very limited number of long-term datasets of sub-micron aerosol particle size distributions. Even from the Indo gangetic basin basin, where several intensive measurement campaigns have been carried out during recent years, no size distribution measurements that cover a full year have been published (see, for example, the review by Lawrence and Leliveld (2010)). Most probably it is the first study of its kind to understand the aerosol number concentration behavior and its origin during two different seasons over this region.

The possible sources of aerosols on a regional scale over India have only recently received attention. In the present study, we identify potential source regions of the factors during the event using Potential Source Contribution Function (PSCF), and combine it with particle number concentration for source identification. Several observations of aerosol concentrations have been made over North Western India (Verma et al., 2013; Payra et al., 2013). The general trend over the site during pre-monsoon season was high AOT and low AE values and vice-versa in winter. The in-situ measurements for 2011 have also shown the similar trends of AOT and AE. However, AOT and AE were little bit higher and lower than the mentioned respective values. In-situ measurements are thus important especially at strategic places like Jaipur which can help determine the regional radiation budget over a semi-arid region.

In continuation to above, in this paper the concentration of different sized particles, during two contrasting seasons i.e. winter and summer time are studied over Jaipur, Northwestern India. Specially, the characteristics of modes appearing in measured particle size distributions in combination with MICROTOP II sunphotometer data are investigated. The purpose of this study is to determine the characteristic of aerosol size distribution at Jaipur during two extreme seasons by examining the simultaneously measured size-separated number concentrations. 


\section{Instrumentation and Data used}

\subsection{Site Description}

Jaipur, the study area, lies in desert belt receiving most of the rain during late summer months. The measurement site is located about $6 \mathrm{~km}$ to east from the Jaipur city centre. The climate of the region has three distinct seasons; summer (April-June), monsoon (July-September) and harsh winter (December-January). Figure 1 shows meteorological conditions of site retrieved from National Center for Environmental Prediction (NCEP) National Center for Atmospheric Research (NCAR) reanalysis data. The rainfall values used in Figure 1 taken from Department of Water Resource, Government of Rajasthan; (http://waterresources.rajasthan.gov.in/Daily_Rainfall_Data/Rainfall_Index.htm). The average temperature during 2011 at Jaipur increases from $14.4^{\circ} \mathrm{C}$ in January to become maximum $35.2^{\circ} \mathrm{C}$ in May and thereafter it fell to $17.5^{\circ} \mathrm{C}$ in December. Wind speed at Jaipur gradually seems to decrease from $11.8 \mathrm{~km} / \mathrm{h}$ in May to $3.8 \mathrm{~km} / \mathrm{h}$ in November. The wind direction at Jaipur shows its flow mostly from south-west (from the Thar Desert area of India). The relative humidity shows an increase from $\sim 18 \%$ in April to $\sim 88 \%$ in August. Thereafter RH again decreases to $\sim 32 \%$ in October showing thereby that summer is less humid than monsoon but more humid than the onset of winter season.

\subsection{Instruments used}

The ground-based aerosol measurements have been carried out at Birla Institute of Technology (BIT), Jaipur, India (26.9 N, $75.8 \mathrm{E}$ and $450 \mathrm{~m}$ altitude from mean sea level) using handheld MICROTOPS II sun-photometer from morning to evening during April to December 2011 on clear sky days. The MICROTOP II (Solar Light Company, USA) is a hand-held multi-band sun-photometer capable of measuring the AOT by direct solar irradiance in each band. MICROTOP II provides aerosol optical thickness (AOT) and columnar water vapor from instantaneous measurement at five channels with full field of view of $2.5^{\circ}$. The instrument measures the intensity of direct solar irradiance at five narrow-band spectral channels centered at 440, 500, 675, 870 and $936 \mathrm{~nm}$ and gives corresponding AOT. Sun photometers are specialized narrow field-of-view radiometers designed to measure solar irradiance (Shaw, 1983). The handheld sun-photometer 
measures attenuation of the direct sunlight as it passes through the atmosphere. As instrument's aperture is small, sun-photometer measure light intensity is usually not influenced by atmospheric scattering, at least for moderate AOT value.

Aerosol number concentration data is retrieved from Grimm Aerosol Spectrometer i.e. Grimm model 1.108 portable aerosol spectrometers (Grimm Aerosol Technik GmbH, Germany) over the site location. For observations at Jaipur, Grimm is configured in particle count mode (particle/l) in 15 different size channels at 15-min time interval. The Grimm Aerosol Spectrometer measures the particle number concentrations in an optical size of 0.3-20 $\mu \mathrm{m}$ with 15 differently size ranges (Mohan and Payra, 2006). The Grimm Aerosol Spectrometer measures the number of particles per unit volume of air using light-scattering technology, in which a semiconductor laser serves as light source. The machine uses an internal air-sampling pump (1.2 1/min) for single particle count. The detail information of this monitor can be found in Cheng and Lin (2010).

\subsection{Potential Source Contribution Function (PSCF)}

Receptor modeling approaches such as Potential Source Contribution Function (PSCF) is effective tool in source identification of urban and regional-scale pollution. In this work, Potential Source Contribution Function (PSCF) analysis is applied to identify locations of sources that influenced concentrations of aerosols over study area in two different seasons. The PSCF is a conditional probability function that describes the spatial distribution of probable source locations of the atmospheric pollutants in a geophysical region. PSCF derives the information on the various sources of aerosols during different seasons and varying contribution from different source regions.

PSCF explicitly incorporate the airborne concentration data and air parcel backward trajectories and estimates the conditional probability function that an air parcel with a specified level of a pollutant concentration arrived at a receptor site after having passed through a specific region (Cheng et al., 1993; Gao et al., 1996; Kindap et al., 2006; Mehta et al., 2009; Neimi et al., 2009). The PSCF in an $i j$-th grid cell of a geophysical region is defined as: 


$$
P S C F_{i j}=\frac{P\left(B_{i j}\right)}{P\left(A_{i j}\right)}
$$

where $P\left(\mathrm{~B}_{\mathrm{ij}}\right)$ is the probability of occurrence an event if the trajectories segment endpoints associated with the concentrations higher than a pre-specified threshold (criteria) value arrived in the $i j$-th grid cell, and $P\left(\mathrm{~A}_{\mathrm{ij}}\right)$ is the probability of an event of all trajectories segment endpoints passed through the same $i j$-th grid cell in that region. Due to a higher degree of uncertainty associated with the grid cells with small number of trajectory endpoints, an arbitrary weight function (Zheng and Hopke, 1989) was used to reduce the values of the PSCF in that grid cells. The values of PSCF lie between 0 and 1. Locations corresponding to the higher values of PSCF are likely to be the potential source regions of a pollutant; whereas, grid cells corresponding to the smaller values of the PSCF are unlikely to be the source regions.

\section{Results and Discussion}

\subsection{Variations of particle number concentrations}

Size distributions of atmospheric aerosols may be described in terms of modes which characterize their size ranges. Sub micrometer particles are classified into the total aerosols number concentration TANC modes $\left(D_{p}=0.3-20 \mu \mathrm{m}\right)$, fine aerosols number concentration i.e. FANC $\left(D_{p}=0.3-2 \mu \mathrm{m}\right)$ and the coarse i.e. CANC $\left(D_{p}=>2 \mu \mathrm{m}\right)$

\subsubsection{Seasonal variation}

An insight into the seasonal variation of the aerosol size distribution may initially be gained by comparing TANC, CANC and FANC in Figure 2a and 2b, where 15 minutes average values from May, 2011 to December, 2011 except $28^{\text {th }}$ July, 2011 to $27^{\text {th }}$ September, 2011 are presented over Jaipur. The instrument was in maintenance from $28^{\text {th }}$ July, 2011 to $27^{\text {th }}$ September, 2011

The Total Aerosol Number Concentrations (TANC, 0.3-20 $\mu \mathrm{m}$ ) variations with time are presented in Figure 2a. A wide variation in aerosol concentrations from season to season is seen. A clear gradient in number concentrations is marked where minimum value is 
$2.1 \times 10^{4}$ particles $/ 1$ on $26^{\text {th }}$ May, 2011 and maximum is $2.3 \times 10^{6}$ particles $/ 1$ on $3^{\text {rd }}$ December, 2011. Particles density is higher in winter than in summer. The higher density of aerosol number concentration in winter is due to the contribution of fine mode particle concentration which is showing in Figure 2(a). Figure 2(b) shows that the aerosol number concentration of fine particle increases from May to December 2011. The coarse modes are characterized by high concentrations during summer which originate from the stronger influence of high air masses as illustrated in Figure 1 for typical summer days during summer months.

\subsubsection{Diurnal Variation of Aerosol number concentration during summer and winter}

An analysis of diurnal variations in aerosol number concentrations allows insight into the dominant size range during each season. Diurnal averages for the two seasons were calculated with a time resolution of 1 hour and appear in Figures 3(a)-(c).

Comparison of average diurnal pattern of particle number concentrations of different size ranges between two contradictory seasons has been carried out in this section. The diurnal variations of the total aerosols number concentration, coarse and fine particles during summer and winter seasons are presented in Figures $3 \mathrm{a}, 3 \mathrm{~b}$ and $3 \mathrm{c}$, respectively. In 3a, strongest peak occurs around 08:00 AM of winter and then it dispersed as day increases. A secondary maximum appeared around 09:00 PM in evening when the atmosphere is reaching again in stability. After that concentration decreases due to coagulation and settling down of the aerosols in the stable atmosphere. The average value of TANC is $9.7 \times 10^{5}$ and $6.8 \times 10^{6}$ particles/l in summer and winter respectively. The comparison of the total particle concentration shows less particle burden during summer season.

In the contrary, the peak for coarse particle happens during the afternoon time of summer when the turbulence in atmosphere is too high (Figure 3b) due to the high temperature and wind speed. The stable atmospheric condition endorsed the particles to be accumulated in the urban atmosphere as evident from meteorological variables. The 
emissions mostly get trapped in low mixing layer due to cold night as the nocturnal inversion layer also reaches near the Earth's surface in winter. The diurnal patterns of particles are closely related to morning traffic and meteorological conditions (low mixing height).

The shapes of the curves of diurnal variation in the mean FANC averaged for the time of the day during winter and summer are rather different (Figure 3c). The peak value of FANC during winter season it reaches up to $9.16 \times 10^{5} \mathrm{~cm}^{-3}$ at 08:00 hrs. FANC has a high value in morning, decreases slightly till around noon, and gradually stabilizes and becomes almost constant towards evening and then rises again. The maximum value of fine ANC during winter found at 08:00 hrs may be due to stable atmospheric condition. A clear gradient in fine aerosols number concentrations during winter at around $6.99 \times 10^{5}$ $\mathrm{cm}^{-3}\left( \pm 6.13 \times 10^{5} \mathrm{~cm}^{-3}\right)$, to summer $9.64 \times 10^{4} \mathrm{~cm}^{-3}\left( \pm 5.53 \times 10^{4} \mathrm{~cm}^{-3}\right)$. The high ratio in particle number concentrations observed in the ground-based site is unlikely to be explained by dispersion processes alone. This may be attributed to the traffic volume and other local sources. The peak value of FANC during winter season is $1.24 \times 10^{5} \mathrm{~cm}^{-3}$ at 21:00 hrs during summer. In case of coarse particle concentration it found maximum at 14:00 hrs due to turbulence and second peak at 09:00 hrs due to air breeze while minimum concentration found at 03:00 and 05:00 hrs during summer and winter respectively.

The large day-to-day variability which is observed throughout the study period primarily results from meteorological influences. Special consideration of analysis of atmospheric temperature inversions is thus required as these are regularly occurring phenomena during the winter season, notably affecting the investigated area. During such events, an accumulation of the particle load takes place, leading to an increased exposure of aerosols as seen in Figure 3.

\subsection{Seasonal variation of AOT}

The maximum value of AOT in winter season is 0.94 at $2^{\text {nd }}$ December 10:00 am whereas in summer season the value obtained is 1.9 at $8^{\text {th }}$ April 16:00 pm as shown in Figure 4. 
Aerosol optical thickness (AOT) and Angstrom Exponent (AE) were observed $~ 0.66$ and $\sim 0.3$ respectively, during pre-monsoon season over Jaipur. However, during winter season, AOT and AE were $\sim 0.50$ and $\sim 1.15$ respectively. The variation of AOT in winter is lower than the summer. Table 1 shows the statistical analysis for AOT and AE during summer and winter. Table shows that that the difference of AOT during summer and winter seasons is small but the difference of AE during these two seasons is very high. The difference in mean AOT and AE values reveals that the AOT is almost the same order during both seasons while AE shows the drastic change. The low AE value shows the presence of coarse particle during summer while high value of AE indicates the dominance of fine particle during winter. AOT at all wavelengths are high during summer, prior to the monsoon. Then the AOT value decreases as monsoon rain washes out the pollutants present in the atmosphere. There are few spikes of AOT is seen irrespective of seasons. $21^{\text {st }}$ May, $25^{\text {th }}$ June and $22^{\text {nd }}$ November shows the more-or-less same AOT value. But by alone AOT, it can't be distinguish the size/nature of the particle.

Figure 4 shows the variation of AOT and AE to see the physical properties of aerosols. A $E(\alpha)$ is one of the most important parameter, which gives an idea about aerosol particle size. The $\mathrm{AE}$ is often used as a qualitative indicator of aerosol particle size, because the spectral shape of the extinction is related to the particle size (Eck et al., 1999; Schuster et al., 2006). The Angstrom parameter $\alpha$ gives the instantaneous value of the turbidity of the atmosphere (Cachorro et al., 1987). In spite of the poor correlation between the AOT and $\alpha$ parameter (Holben et al., 1998), values of both quantities must be considered for a realistic analysis. In the present study, Angstrom parameters were studied in the spectral range of 440-870 $\mathrm{nm}$. Angstrom parameter provides the contribution of fine and coarse particles. Minimum values of $\alpha$ indicate the presence of coarse-mode aerosol particles whereas higher values indicate the dominance of fine-mode particles in Figure 4. The contrast of highest AOT and lowest mean AE were observed in summer season, indicating a relatively high ratio of large particles to small particles due to dust loading in this season. Summer time shows the lower AE $(0.298 \pm 0.188)$ i.e. coarser particles are dominating. In winter it is showing the dominance of fine particles as $\mathrm{AE}(1.155 \pm 0.057)$ is more. 


\subsection{Size Distribution through AOT}

The aerosols optical thickness shows nearly similar AOT values during summer (0.65) and winter (0.50) however corresponding AE values differs during summer $(<0.3)$ than winter $(>1.0)$, respectively shown in figure 5a. The analysis again infers the above results that in summer the coarse particle ( $>2 \mathrm{um}$ ) are high while winter is dominated by fine particles over the study region. The contribution of fine and coarse particle is shown in Figure 5 (b). It shows that the contribution of coarse particle found maximum in month of May $(\sim 4.2 \%)$ and it decreases till December and found minimum ( 0.2\%) contribution of coarse particle in this month. In contrary, the contribution of fine particles in winter is nominally below than $100 \%$. So it shows the percentage difference in fine and coarse modes was found to be higher during winter months and lower (Figure 5 b) during summer.

\subsection{Log - normal size distribution}

Comparison of size resolved number concentration for both seasons is shown in Figure 6. The variation in size distribution of aerosols during two seasons is clearly reflected in the $\log$ normal size distribution curves. It has already discussed that the total ANC is higher in winter compare to summer. Log normal size distribution shows that the particles of size less than $0.8 \mu \mathrm{m}$ dominate during winter while concentration of large particle dominates in summer. The difference grew larger as we move to coarser particle size range. Particles smaller than 0.8 micrometer (at aerodynamic size) constitute $\sim 99 \%$ of all particles in winter and $\sim 90 \%$ of particles in summer season. However, particles greater than $2 \mu \mathrm{m}$ contribute $\sim 3 \%$ and $\sim 0.2 \%$ in summer and winter seasons respectively.

\subsection{PSCF Analysis}

The processes discussed above, however, do not explain the observed higher coarse particles during summer and lesser during winter. The AOT for both seasons remain fairly constant but exhibits different $\mathrm{AE}$ values on average more than two times higher than during summer conditions. An explanation may be due to the difference in the 
sources of aerosols during both seasons and can be derived by the potential source contribution function (PSCF). The PSCF analysis suggests that the seasonal heterogeneity in aerosol characteristics can be attributed to the varying contribution from different source regions. The PSCF analysis is performed to elucidate the influence of transport of coarse and fine particles and to locate the major source regions of these pollutants.

Air parcel back trajectories were computed using HYbrid Single-Particle Lagrangian Integrated Trajectory (HYSPLIT) model (Draxler and Rolph, 2012) and the NCEP/NCAR Reanalysis archived meteorological data from National Oceanic Atmospheric Administration's (NOAA) Air Resources Laboratory (ARL). These back trajectories were computed from May, 2011 to December, 2011 at $500 \mathrm{~m}$ above ground level (agl), starting from the monitoring site at Jaipur (26.92 N, $75.82 \mathrm{E}) .500 \mathrm{~m}$ height was chosen to diminish the effects of surface friction and to represent winds in the lower boundary layer (Begum et al., 2005). Each trajectory was computed backward to 24 hours, at 1-hour interval. The extreme segment endpoints from the computed 24-hours back trajectories for a period from May, 2011 to December, 2011 were used to define the geophysical region. The region was divided to $1^{0}$ longitudes by $1^{0}$ latitude grid cells to compute the PSCF.

In this study, the mean values of the fine and coarse particles number concentration were used as the criterion as in many previous studies (Hsu et al., 2003). For fine and coarse particles, the criterion values are 297615 and 1611, respectively. The PSCF analysis was also performed for the $80^{\text {th }}$, and $90^{\text {th }}$ percentile values for fine and coarse particles number concentration as the criterion values. However, PSCF plots with mean criteria values were readily interpretable for both fine and coarse particles modes and discussed in this study. The spatial variations of the PSCF values were plotted with ArcGIS V9.3 using an inverse distance weighting (IDW) interpolation scheme.

Figures 7 (a) \& (b) shows the spatial distribution of the PSCF values for fine and coarse particles superimposed over a map. Figure 7 (a) shows the higher PSCF values for fine particles coming from north and east of Jaipur. These higher values of the PSCF in north and east from Jaipur showed the industrial areas in northern India to be the likely 
sources of fine particles. And the wind direction gives an impression that the contribution is mainly in winter as the prevailing wind direction of winter is north-east. Higher values of the PSCF for coarse particles were appeared in south-west of Jaipur (Figure 7(b)). The prevailing wind speed in summer is south-west. Summer is dry with high wind speed in the arid region. The PSCF profile shows the adjacent Desert region centered in western India and eastern Pakistan to be major sources areas of the coarse particles. It also illustrates that the dust particles from Desert contribute significantly to the coarse mode concentration of aerosols at Jaipur.

\section{Summary and Conclusion}

During an extended study at Jaipur site (450 $\mathrm{m}$ amsl), the particle number size distribution (diameter $\mathrm{D}_{\mathrm{p}}=0.3-20 \mu \mathrm{m}$ ) and aerosols optical thickness were measured on a continuous basis. The winter and summer seasons with a contrast temperature characteristics in the year 2011 are investigated in the present study.

The number size distribution was dominated by fine particles during winter season. The log normal size distribution curves reveals that the particle size less than 0.8 $\mu \mathrm{m}$ has key contributor in winter for higher ANC. The aerosols optical thickness shows nearly similar AOT values during summer and winter however corresponding AE values differs during summer $(<0.3)$ than winter $(>1.0)$, respectively. The analysis again infers the above finding that in summer the coarse particle $(>2 \mu \mathrm{m})$ are high while winter is dominated by fine particles over the study region. The Potential Source Contribution Function (PSCF) analysis also helped to understand the major source regions of these particles. PSCF analysis shows that the coarse particles come from south-west direction so desert contributes significantly to the coarse mode concentration of aerosols. But fine particles contribution mainly from north-east direction which happens during winter. The path length for contribution of fine particles is small due to the stability which again gives an impression that the contribution is mainly in winter whereas the path length of coarse particles is longer due to high wind speed and turbulence which occurs in summer time. 


\section{Acknowledgements}

We greatly acknowledge and thank SERB, Department of Science and Technology (DST), Govt. of India for financial support under research project SR/S4/AS:39/2009. Authors gratefully acknowledge the NOAA Air Resources Laboratory (ARL) for the provision of the HYSPLIT transport and dispersion model and/or READY website (http://www.arl.noaa.gov/ready.php) used in this publication.

\section{References}

Begum, B. A., Kim, E., Jeong, C. H., Lee, D. W., Hopke, P. K., 2005. Evaluation of the potential source contribution function using the 2002 Quebec forest fire episode. Atmospheric Environment, 39(20), 3719-3724.

Bhanarkar, A. D., Gajghate, D. G., Hasan, M. Z., 2002. Assessment of air pollution from small scale industry. Environ Monit Assess 80: pp. 125-133.

Buzorius, G., Hämeri, K., Pekkanen, J., Kulmala, M., 1999. Spatial variation of aerosol number concentration in Helsinki city. Atmospheric Environment, 33(4), 553565.

Cachorro, V. E., Gonzalez, M. J., De Frutos, A. M., Casanova, J. L., 1989. Fitting Ångström's formula to spectrally resolved AOT. Atmospheric Environment (1967), 23(1), 265-270.

Chatterjee, A., Adak, A., Singh, A. K., Srivastava, M. K., Ghosh, S. K., Tiwari, S., Devara, P.C.S., Raha, S., 2010. Aerosol chemistry over a high altitude station at northeastern Himalayas, India. PloS one, 5(6), e11122.

Cheng, M. D., Hopke, P. K., Barrie, L., Rippe, A., Olson, M., Landsberger, S., 1993. Qualitative determination of source regions of aerosol in Canadian high Arctic. Environmental Science and Technology, 27(10), 2063-2071.

Cheng, Y. H., Lin, Y. L., 2010. Measurement of particle mass concentrations and size distributions in an underground station. Aerosol Air Qual. Res, 10, $22-29$.

Draxler, R. R., Rolph, G. D., 2012. HYSPLIT (HYbrid Single-Particle Lagrangian Integrated Trajectory). NOAA Air Resources Laboratory READY Website.

Eck, T. F., Holben, B. N., Reid, J. S., Dubovik, O., Smirnov, A., O'neill, N. T., Slutsker, I., Kinne, S., 1999. Wavelength dependence of the optical depth of biomass 
burning, urban, and desert dust aerosols. Journal of Geophysical Research: Atmospheres (1984-2012), 104(D24), 31333-31349.

Gajananda, K., Kuniyal, J. C., Momin, G. A., Rao, P. S. P., Safai, P. D., Tiwari, S., Ali, K., 2005. Trend of atmospheric aerosols over the north western Himalayan region, India. Atmospheric Environment, 39(27), 4817-4825.

Gao, N., Hopke, P. K., W. Reid, N., 1996. Possible sources for some trace elements found in airborne particles and precipitation in Dorset, Ontario. Journal of the Air \& Waste Management Association, 46(11), 1035-1047.

Harrison, R.M., Jones, M., Collins, G., 1999. Measurements of the physical properties of particles in the urban atmosphere. Atmos. Environ 33, 309-321.

Holben, B.N., Eck, T.F., Slutsker, I., Tanré, D., Buis, J.P., Setzer, A., Vermote, E., Reagan, J.A., Kaufman, Y.A., 1998. AERONET-a federated instrument network and data achieve for aerosol characterization. Remote Sens. Environ. 66, 1-16.

Hsu, Y.K., Holsen, T.M., Hopke, P.K., 2003. Comparison of hybrid receptor models to locate PCB sources in Chicago. Atmospheric Environment 37, 545-562.

Hussein, T., Puustinen, A., Aalto, P.P., Makela, J.M., Hameri, K., Kulmala, M., 2004. Urban aerosol number size distributions. Atmos. Chem. Phys. 4, 391-411.

Kindap, T., Unal, A., Chen, S.-H., Hub, Y., Odman, M.T., Karaca, M., 2006. Longrange aerosol transport from Europe to Istanbul, Turkey. Atmospheric Environment 40 (19), 3536-3547.

Kulshrestha, U. C., Rao, T. N., Azhaguvel, S., Kulshrestha, M. J., 2004. Emissions and accumulation of metals in the atmosphere due to crackers and sparkles during Diwali festival in India. Atmospheric Environment, 38(27), 4421-4425.

Kumar, A., Sarin, M. M., 2009. Mineral aerosols from western India: temporal variability of coarse and fine atmospheric dust and elemental characteristics. Atmospheric Environment, 43(26), 4005-4013.

Lawrence, M. G., Lelieveld, J., 2010. Atmospheric pollutant outflow from southern Asia: a review. Atmospheric Chemistry and Physics, 10, 11017-11096.

Majumdar, D., Nema, P., 2011. Assessment of fine particle number profile in fugitive emission from firecrackers. J. Sci. Indus. Res, 70. 
Mehta, B., Venkataraman, C., Bhushan, M., Tripathi, S.N., 2009. Identification of sources affecting fog formation using receptor modeling approaches and inventory estimates of sectoral emissions. Atmospheric Environment 43 (6), $1288-1295$.

Mitra, A. P., Sharma, C., 2002. Indian aerosols: present status. Chemosphere, 49(9), 1175-1190.

Mohan, M., Payra, S., 2006. Relation between fog formation and accumulation mode aerosols in urban environment Delhi, India. Indian Journal of Environmental Protection, Volume 26, No. 4, pp 294-300.

Niemi, J.V., Saarikoski, S., Aurela, M., Tervahattu, H., Hillamo, R., Westphal, D.L., Aarnio, P., Koskentalo, T., Makkonen, U., Vehkamaki, H., Kulmala, M., 2009. Long-range transport episodes of fine particles in southern Finland during 19992007. Atmospheric Environment 43, 1255-1264.

Pant, P., Hegde, P., Dumka, U. C., Saha, A., Srivastava, M. K., Sagar, R., 2006. Aerosol characteristics at a high-altitude location during ISRO-GBP Land CampaignII. Current Science, 91(8), 1053-1061.

Pant, V., Deshpande, C. G., Kamra, A. K., 2010. Changes in concentration and size distribution of aerosols during fog over the south Indian Ocean. Journal of Earth System Science, 119(4), 479-487.

Payra, S., Verma, S., Prakash, D., Kumar, P., Soni, M., Holben, B., 2013. Aerosols properties during dust-storm episodes over Jaipur, Northwestern India. In NUCLEATION AND ATMOSPHERIC AEROSOLS: 19th International Conference (Vol. 1527, No. 1, pp. 515-518). AIP Publishing.

Prakash, D., Payra, S., Verma, S., Soni, M., 2013. Aerosol particle behavior during Dust Storm and Diwali over an urban location in north western India. Natural hazards, 69(3), 1767-1779.

Remer, L.A., Kaufman, Y.J., Tanré, D., Mattoo, S., Chu, D.A., Martins, J.V., Li, R.-R., Ichoku, C., Levy, R.C., Kleidman, R.G., Eck, T.F., Vermote, E., Holben, B.N., 2005. The MODIS Aerosol Algorithm, Products, and Validation. J. Atmos. Sci., 62, 947-973. 
Saha, U., Talukdar, S., Jana, S., Maitra, A., 2014. Effects of air pollution on meteorological parameters during Deepawali festival over an Indian urban metropolis. Atmospheric Environment, 98, 530-539.

Schuster, G. L., Dubovik, O., Holben, B. N., 2006. Angstrom exponent and bimodal aerosol size distributions. Journal of Geophysical Research: Atmospheres (19842012), 111(D7).

Schwartz, S.E.,Arnold, F., Blanchet, J.-P., Durkee, P.A., Hofmann, D.J., Hoppel, W.A., King, M.D., Laos, A.A., Nakajima, T., Ogren, J.A., Toon, O.B., Wendisch, M., 1995. Group Report: Connections between aerosol properties and forcing of climate. John Wiley, Hoboken, N.J., pp. 251-280.

Sharma, N. L., Kuniyal, J. C., Singh, M., Sharma, P., Chand, K., Negi, A. K., Sharma, M., Thakur, H. K., 2011. Atmospheric ultrafine aerosol number concentration and its correlation with vehicular flow at two sites in the western Himalayan region: Kullu-Manali, India. Journal of earth system science, 120(2), 281-290.

Shaw, G.E., 1983. Sunphotometery. Bull. Am. Meteorol. Soc. 64: 4-10.

Singh, R. P., Dey, S., Holben, B., 2003. Aerosol behaviour in Kanpur during Diwali festival. Current Science, 84(10), 1302-1304.

Stanier, C.O., Khlystov, A.Y., Pandis, S.N., 2004. Ambient aerosol size distributions and number concentrations measured during the Pittsburgh Air Quality Study (PAQS). Atmos. Environ 38, 3275-3284.

Verma, S., Payra, S., Gautam, R., Prakash, D., Soni, M., Holben, B., Bell, S., 2013. Dust events and their influence on aerosol optical properties over Jaipur in Northwestern India. Environmental monitoring and assessment, 185(9), 73277342.

Wehner, B., Wiedensohler, A., 2003. Long term measurements of submicrometer urban aerosols: statistical analysis for correlations with meteorological conditions and trace gases. Atmos. Chem. Phys. 3,867-879.

Woo, K.S., Chen, D.R., Pui, D.Y.H., McMurry, P.H., 2001. Measurement of Atlanta aerosol size distributions: observations of ultrafine particle events. Aeros. Sci. Technol 34, 75-87. 
Wu, Z., Hu, M., Lin, P., Liu, S., Wehner, B., Wiedensohler, A., 2008. Particle number size distribution in the urban atmosphere of Beijing, China. Atmospheric Environment, 42(34), 7967-7980.

Zeng, Y., Hopke, P. K., 1989. A study of the sources of acid precipitation in Ontario, Canada. Atmospheric Environment (1967), 23(7), 1499-1509.

Table 1:- Statistical analysis of AOT and AE for Summer and Winter

\begin{tabular}{|c|c|c|c|c|c|c|c|}
\hline & \multirow[b]{2}{*}{ Mean } & \multirow[b]{2}{*}{$\begin{array}{c}\text { Std. } \\
\text { Deviation }\end{array}$} & \multirow[b]{2}{*}{$\begin{array}{l}\text { Std. Error } \\
\text { Mean }\end{array}$} & \multicolumn{3}{|c|}{ Paired Differences (Summer - Winter) } \\
\hline & & & & & Mean & $\begin{array}{c}\text { Std. } \\
\text { Deviation }\end{array}$ & $\begin{array}{c}\text { Std. Error } \\
\text { Mean }\end{array}$ \\
\hline \multirow{2}{*}{ AOT } & Summer & 0.656 & 0.297 & 0.037 & \multirow{2}{*}{0.155} & \multirow{2}{*}{0.115} & \multirow{2}{*}{-0.004} \\
\hline & Winter & 0.501 & 0.182 & 0.041 & & & \\
\hline \multirow{2}{*}{$\mathbf{A E}$} & Summer & 0.298 & 0.188 & 0.024 & \multirow{2}{*}{-0.857} & \multirow{2}{*}{0.131} & \multirow{2}{*}{0.011} \\
\hline & Winter & 1.155 & 0.057 & 0.013 & & & \\
\hline
\end{tabular}

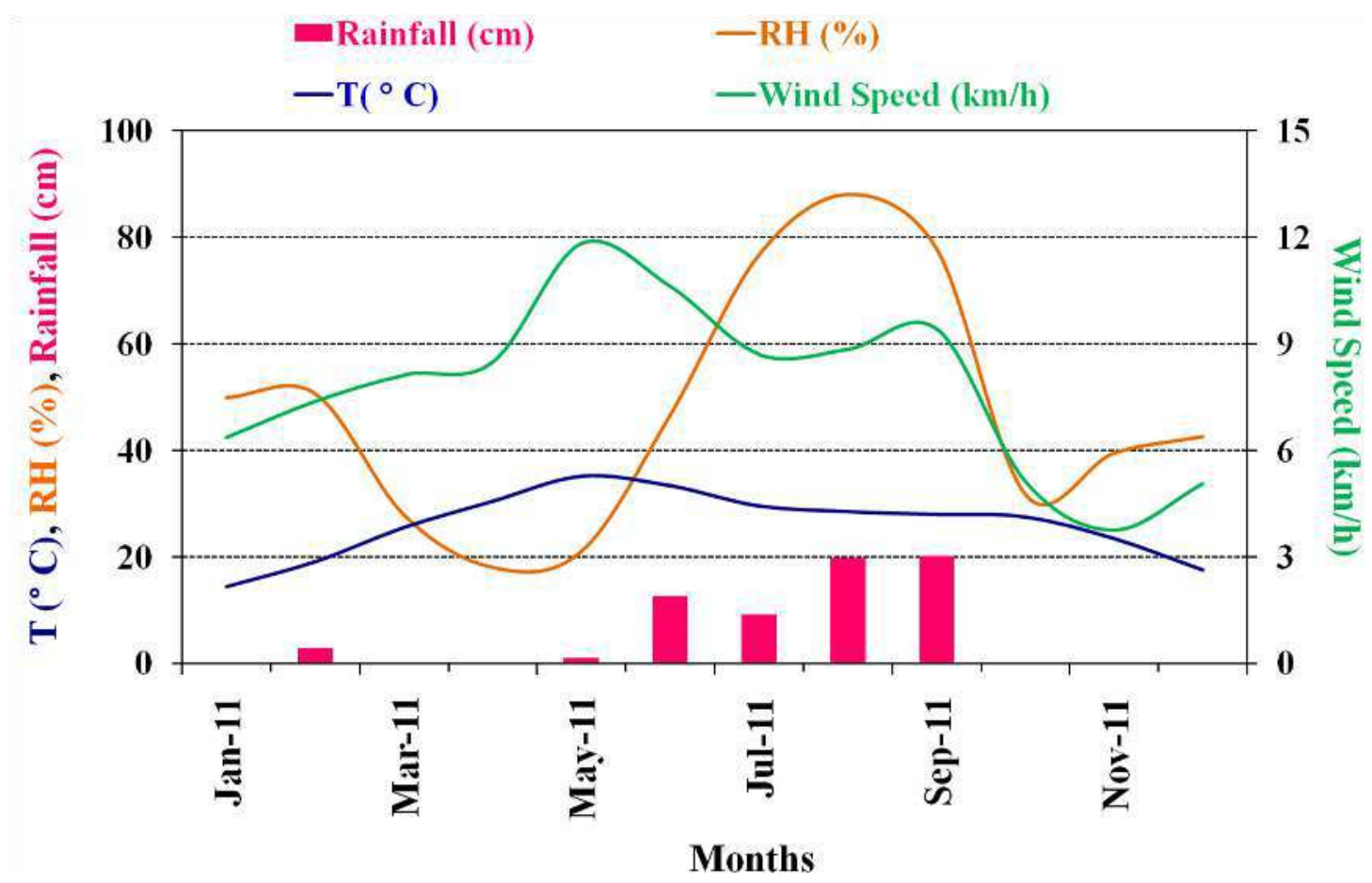

Figure 1: Monthly variation of meteorological parameter over study location. 

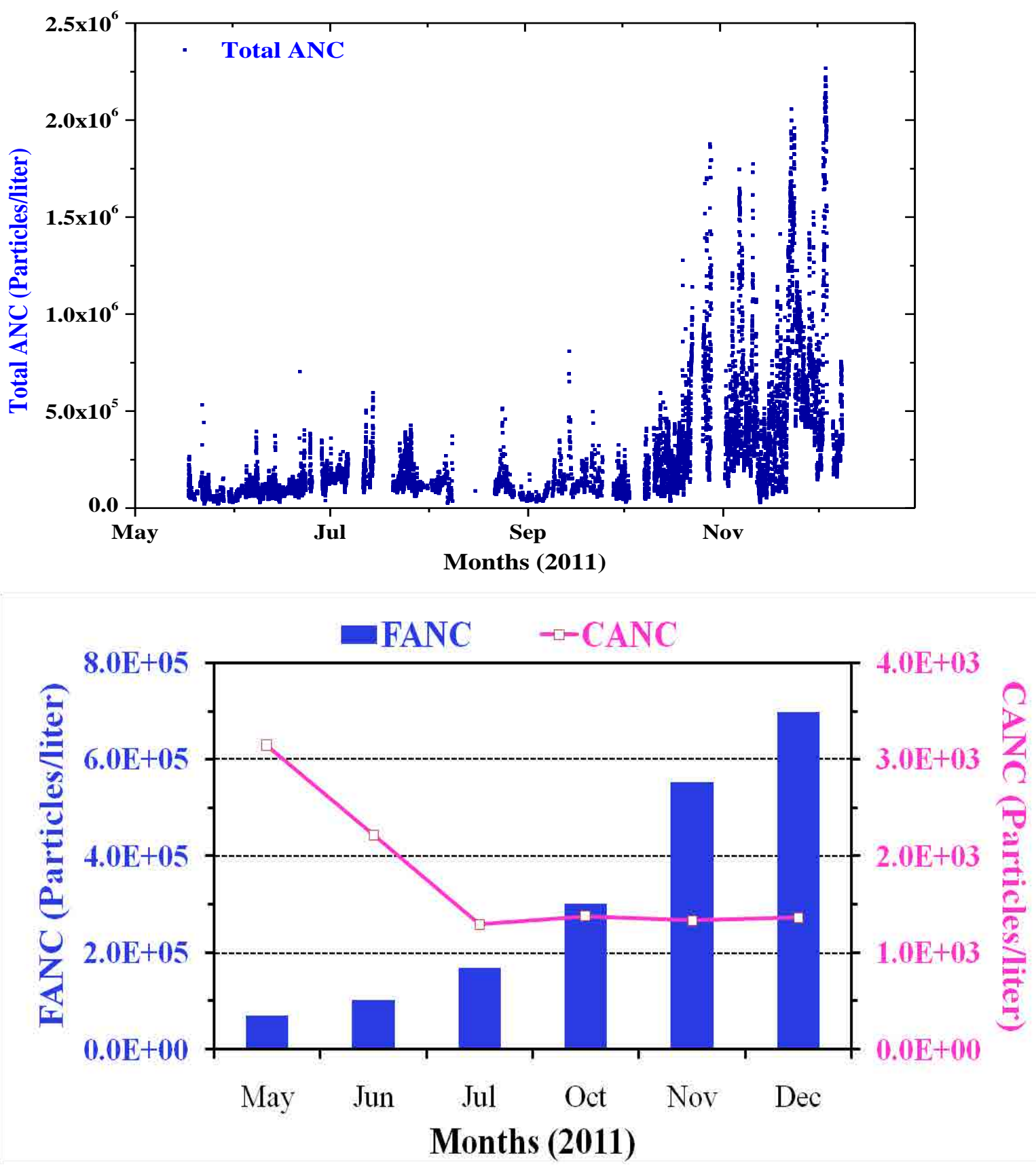

Figure 2: (a) Variation of 15 minute averaged total aerosol number concentration (b) Monthly variation of fine and coarse aerosol number concentration at Jaipur. 


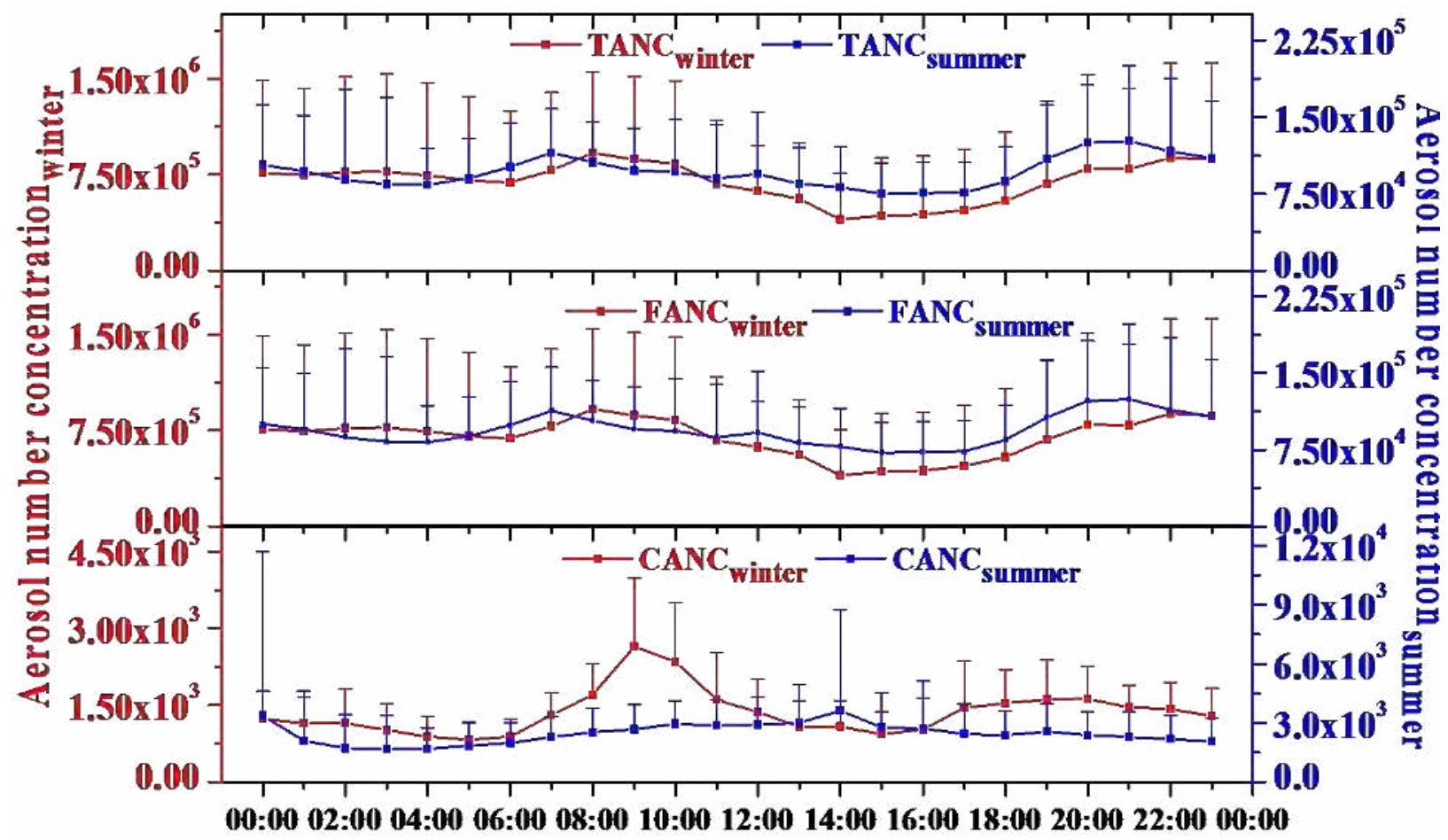

Time (hh:mm)

Figure 3: Diurnal variation of Total ANC, Coarse ANC and fine ANC during summer and winter from May to Dec 2011. 


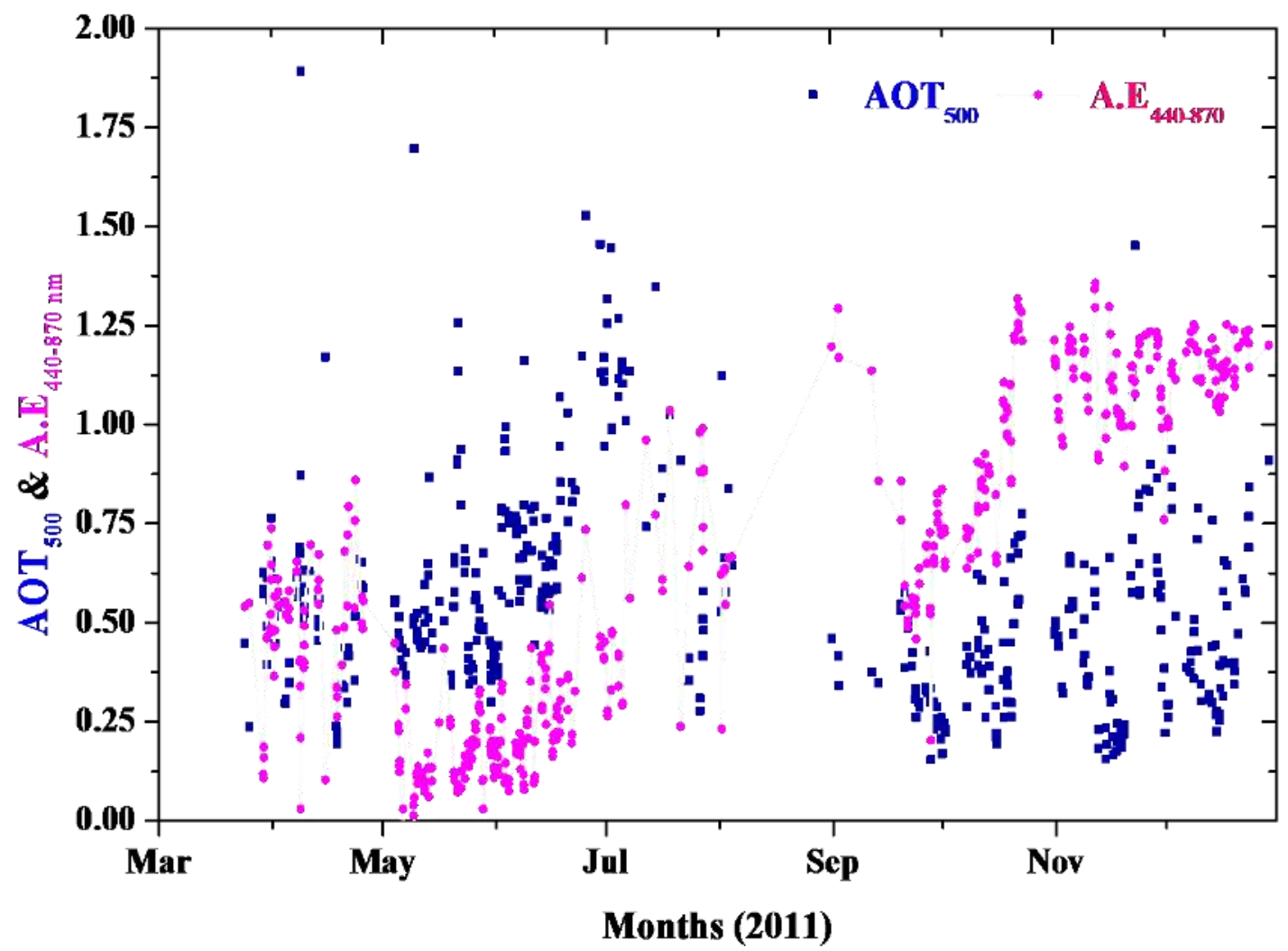

Figure 4: Variation of $\mathrm{AOT}_{500}$ and A.E $440-870$ with time from April to December. 

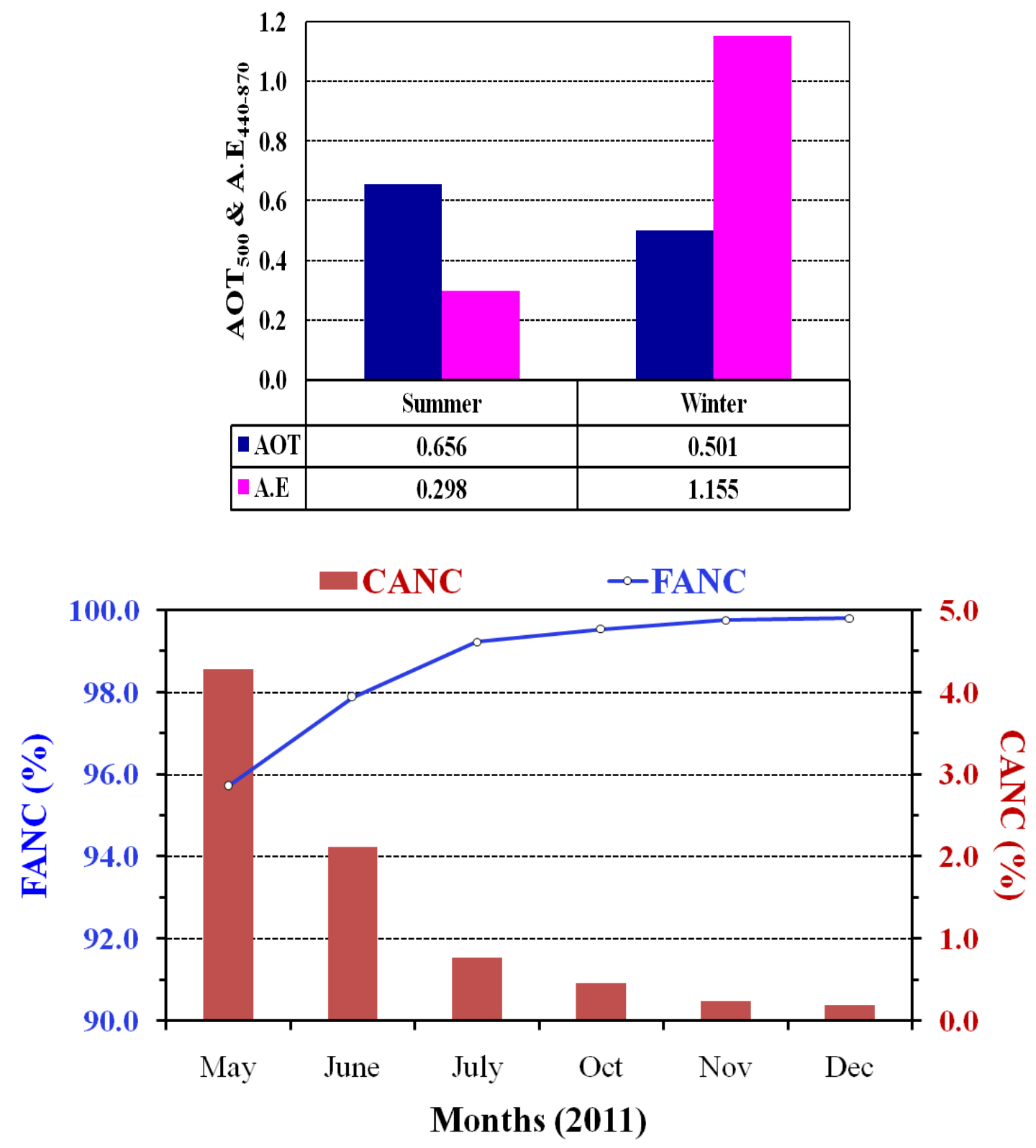

Figure 5: (a) AOT and A.E during summer and winter (b), Percentage contribution of fine and coarse aerosols. 


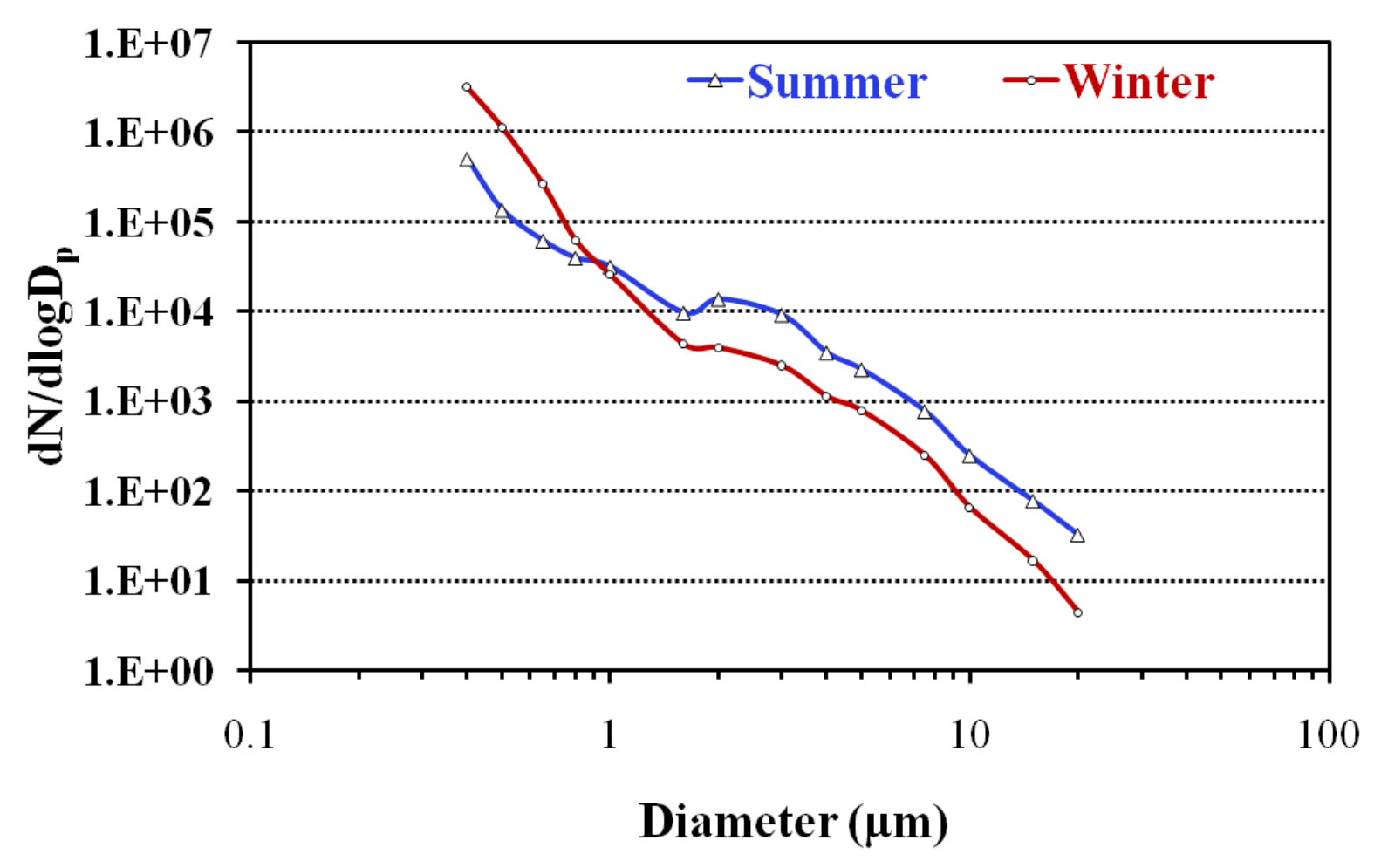

Figure 6: Log normal distribution during summer and winter. 


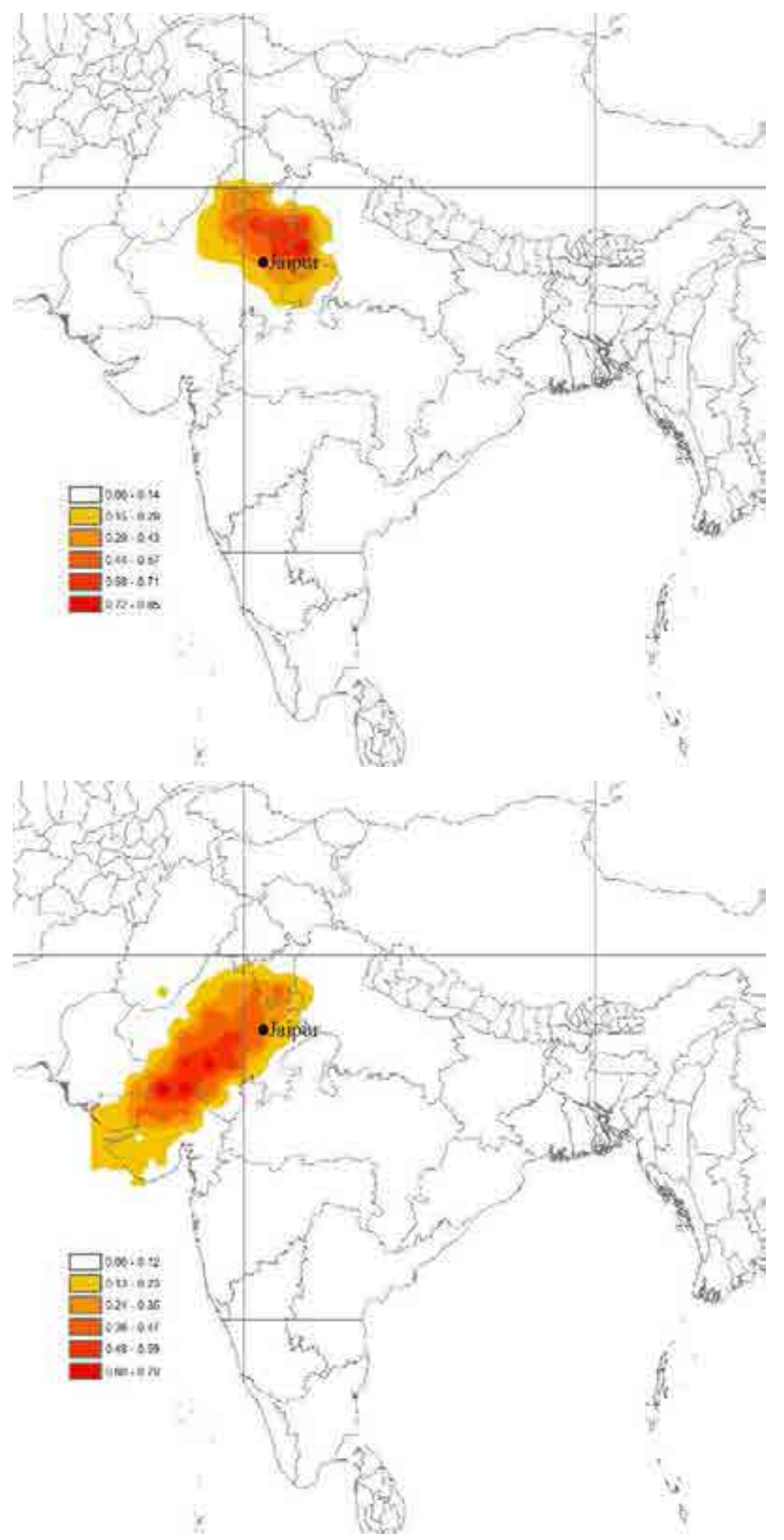

Figure 7: Potential source contribution function (PSCF) plots of (a) fine particles, and (b) coarse particles at Jaipur, Rajasthan, India. 